\title{
Pathophysiology and pharmacological treatment of pulmonary hypertension in acute respiratory distress syndrome
}

\author{
E.D. Moloney, T.W. Evans
}

Pathophysiology and pharmacological treatment of pulmonary hypertension in acute respiratory distress syndrome. E.D. Moloney, T. W. Evans. (C) ERS Journals Ltd 2003. ABSTRACT: Pulmonary hypertension $(\mathrm{PH})$ is a characteristic feature of the acute respiratory distress syndrome (ARDS). The magnitude of $\mathrm{PH}$ has been shown to correlate with the severity of lung injury in patients with ARDS independently of the severity of associated hypoxaemia and has an adverse prognostic significance.

Early in the histopathological evolution of ARDS, pulmonary vasoconstriction, thromboembolism and interstitial oedema contribute to the development of PH, although pulmonary vascular remodelling probably occurs eventually. Intravenous vasodilator agents lead to an increase in intrapulmonary shunting and systemic hypotension, which can limit their therapeutic use, and have not been shown to improve survival. By contrast, rapidly metabolised vasodilators administered by inhalation induce selective pulmonary vasodilatation and decrease shunting, but again do not appear to confer a survival benefit.

Research aimed at further understanding the mechanisms that underlie pulmonary hypertension, a characteristic feature of the acute respiratory distress syndrome, are expected to provide improvements in pharmacological interventions for the treatment of pulmonary hypertension in the acute respiratory distress syndrome.

Eur Respir J 2003; 21: 720-727.
Imperial College School of Medicine, Royal Brompton Hospital, London, UK.

Correspondence: T.W. Evans, Adult Intensive Care Unit, Royal Brompton Hospital, Sydney Street, London, SW3 6NP, UK.

Fax: 442073518524

E-mail: t.evans@rbh.nthames.nhs.uk

Keywords: Acute respiratory distress syndrome pulmonary hypertension

Received: December 232002

Accepted after revision: January 32003

E. Moloney is supported by a European Respiratory Society Fellowship.
Acute respiratory distress syndrome (ARDS) in adults is defined clinically by the acute onset of respiratory failure, with refractory hypoxaemia (arterial oxygen tension $\left(\mathrm{Pa}, \mathrm{O}_{2}\right)$ / inspiratory oxygen fraction $\left(F \mathrm{I}, \mathrm{O}_{2}\right)$ ratio $\left.<26.6 \mathrm{kPa}(200 \mathrm{mmHg})\right)$ and bilateral infiltrates on frontal chest radiographs that cannot be explained by, but may coexist with, elevated left atrial pressure (occluded pulmonary artery pressure $(P$ pa) $<18 \mathrm{mmHg}$ ) [1]. These defining features may be seen in context with a wide range of associated severe medical and surgical conditions, not all of which involve the lung directly. ARDS is the extreme manifestation of a spectrum of acute lung injury (ALI). ALI is defined as the same as ARDS but with less severe refractory hypoxaemia $\left(\mathrm{Pa}, \mathrm{O}_{2} / \mathrm{FI}, \mathrm{O}_{2}<39.9 \mathrm{kPa}\right.$ $(300 \mathrm{mmHg}))$. The epidemiology of ALI, and its pulmonary vascular complications are poorly characterised and only data relating to pulmonary hypertension $(\mathrm{PH})$ in established ARDS will be discussed hereafter.

$\mathrm{PH}$, due to vasoconstriction and occlusion of the pulmonary microvasculature, is widely recognised as a characteristic feature of ARDS [2,3]. The presence of $\mathrm{PH}$ in patients with ARDS, even following correction for the severity of the associated hypoxaemia, was first described in 1977 [2]. Mean Ppa was found to be $\sim 3.99 \mathrm{kPa}(30 \mathrm{mmHg}$; range $0.532-1.33 \mathrm{kPa}$ (4-10 $\mathrm{mmHg})$ ). Since this early report, $\mathrm{PH}$ has been confirmed in larger cohorts of patients with ARDS and is probably a ubiquitous complication of the syndrome. Indeed, some investigators have suggested that ARDS is unlikely in patients with a $P$ pa $<2.66 \mathrm{kPa}(20 \mathrm{mmHg})[1,4-8]$.

\section{Clinical implications}

PH contributes to impaired right ventricular performance and cardiac output in ARDS patients, leading to a reduction in systemic oxygen delivery [9]. In the setting of associated multiple organ dysfunction, $\mathrm{PH}$ may therefore further impair tissue oxygen utilisation and contribute to an increase in organ dysfunction. A correlation between elevations in Ppa and pulmonary oedema has also been demonstrated [10]. Thus, pulmonary interstitial oedema may cause vascular compression and an increase in $P$ pa can promote oedema formation if vasoconstriction develops distal to the site of increased vascular permeability. Secondly, the magnitude of $\mathrm{PH}$ has also been shown to correlate with the severity of lung injury [11]. Thus, resolution of ARDS is accompanied by an improvement in $\mathrm{PH}$, whereas progressive $\mathrm{PH}$ has been shown to be associated with a poor outcome $[2,7,11]$. A multicentre trial in the USA collected haemodynamic data from 153

Previous articles in this Series: No. 1: Humbert M, Trembath RC. Genetics of pulmonary hypertension: from bench to bedside. Eur Respir $J$ 2002; 20: 741-749. No. 2: Galiè N, Manes A, Branzi A. The new clinical trials on pharmacological treatment in pulmonary arterial hypertension. Eur Respir J 2002; 20: 1037-1049. No. 3: Chemla D, Castelain V, Hervé P, Lecarpentier Y, Brimioulle S. Haemodynamic evaluation of pulmonary hypertension. Eur Respir J 2002; 20: 1314-1331. No. 4: Eddahibi S, Morrell N, d'Ortho M-P, Naeije R, Adnot S. Pathobiology of pulmonary arterial hypertension. Eur Respir J 2002; 20: 1559-1572. No. 5: Widlitz A, Barst RJ. Pulmonary arterial hypertension in children. Eur Respir J 2003; 21: $155-176$. 
patients with ARDS for 7 consecutive days [7]. Although Ppa was comparable for all subjects at enrolment, it increased steadily over the 7 study days only in those who failed to survive (mean $P$ pa $33 \mathrm{mmHg}$ in nonsurvivors versus $29 \mathrm{mmHg}$ in survivors, $\mathrm{p}<0.05$ ).

\section{Hypoxic pulmonary vasoconstriction and pulmonary hypertension in acute respiratory distress syndrome}

The canine oleic acid model of lung injury, which bears close pathophysiological and histological similarities to clinical ARDS, is characterised by a significant redistribution of pulmonary blood flow from dependent to nondependent lung regions [12]. This redistribution results from hypoxic pulmonary vasoconstriction (HPV), a mechanism that diverts blood flow from hypoxic to normoxic lung regions, thereby helping to preserve gas exchange. Moreover, preventing this redistribution can increase the deterioration in oxygenation [13]. Similarly, in patients with ARDS, the characteristic refractory hypoxaemia is primarily the result of intrapulmonary shunting and increased ventilation/perfusion $\left(V^{\prime} / Q^{\prime}\right)$ mismatch [14], which is further exacerbated by the administration of intravenous vasodilators [15]. Thus, while the increase in $P$ pa attributable to HPV increases right ventricular afterload, it is a consequence of a physiological reflex designed to preserve $V^{\prime} / Q^{\prime}$ mismatch and attenuate arterial hypoxaemia. However, $\mathrm{PH}$ persists in ARDS, even after severe hypoxaemia has been corrected. Whether HPV persists or not in such patients remains unclear. HPV is a relatively weak mechanism for the homeostatic control of alveolar oxygenation [16]. Several other studies of HPV's overall efficiency have produced variable results [16-18]. ARDS has even been reported to inhibit or abolish HPV. In these patients, the blunted pulmonary vascular response to hypoxia has been attributed to the release of endogenous vasodilator substances e.g. nitric oxide (NO) and prostaglandin $(\mathrm{PG}) \mathrm{I}_{2}[19]$. Whilst the exact mechanisms of HPV are still being evaluated [20], it is clear that NO attenuates the response of pulmonary arteries to hypoxaemia both in vitro and in vivo [21]. In addition, it was observed recently that the increase in $P$ pa, in lung injury, is inhibited by low-dose endotoxin and metabolic alkalosis, factors known to inhibit HPV [22]. This inhibition was incomplete, however, which may reflect the effects on the pulmonary circulation, not only of functional (e.g. active vasoconstriction), but also of anatomical factors that are not rapidly reversible (table 1) [23].

\section{Nonhypoxia increases in pulmonary vascular tone in acute respiratory distress syndrome}

In healthy individuals the endothelium exerts an active control over the tone of the underlying vascular smooth muscle via the synthesis and release of a wide variety of substances (fig. 1). These substances include NO, cyclooxygenase $(\mathrm{COX})$ products including thromboxane $(\mathrm{TX}) \mathrm{A}_{2}$

Table 1.-Factors contributing to pulmonary hypertension in acute respiratory distress syndrome

$\begin{array}{ll}\text { Functional } & \text { Mediator-induced vasoconstriction } \\ & \text { Hypoxic pulmonary vasoconstriction } \\ \text { Structural } & \text { Vascular compression by oedema fluid or fibrosis } \\ & \text { Vascular wall remodelling } \\ & \text { Thromboembolism } \\ & \text { Reduced lung volume }\end{array}$
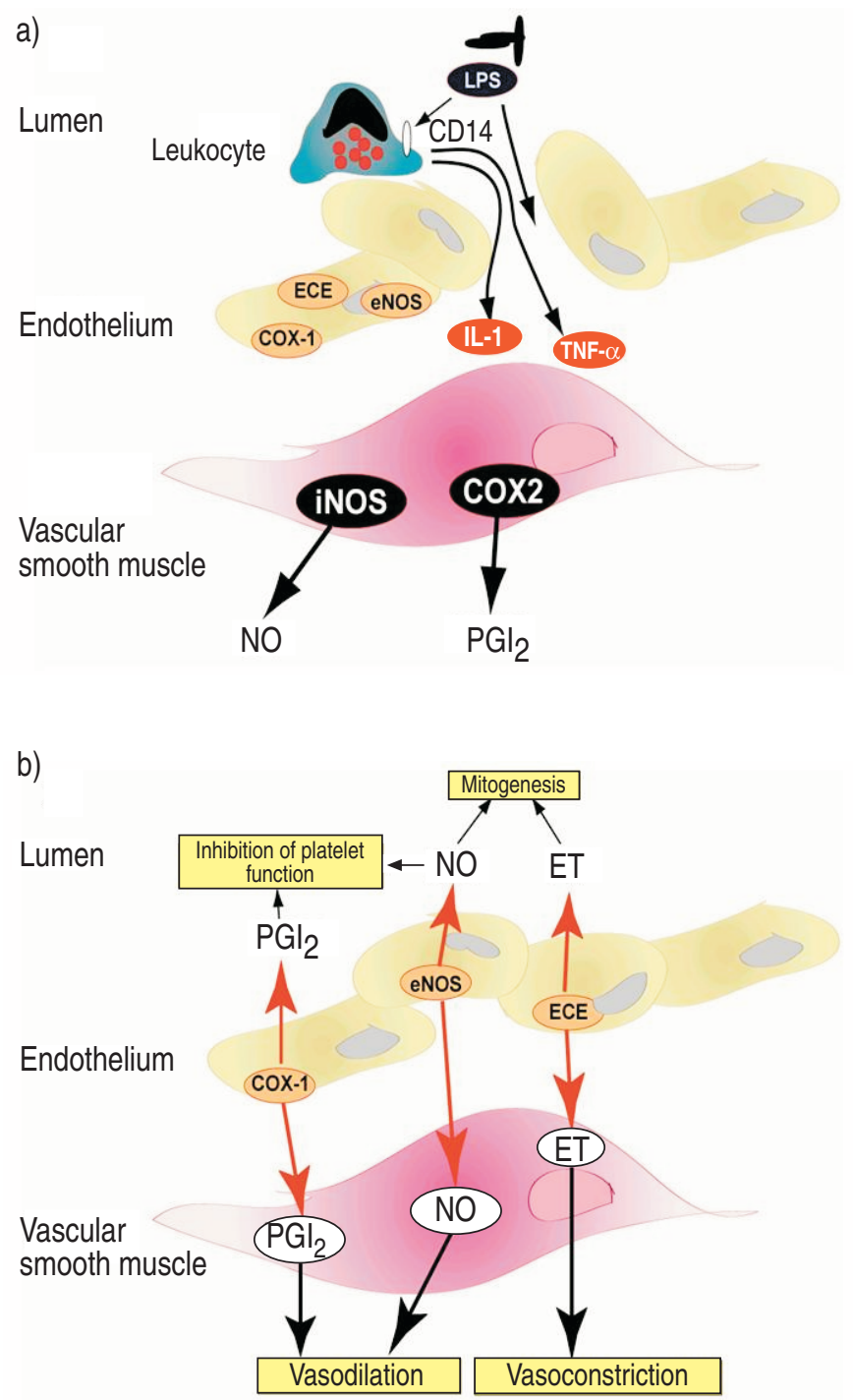

Fig. 1.-Schematic illustration demonstrating some of the major functional changes in the pulmonary circulation in a) vascular smooth muscle and b) endothelium, in patients with acute respiratory distress syndrome. LPS: lipopolysaccharide; NO: nitric oxide; iNOS: inducible nitric oxide synthase; eNOS: endothelial nitric oxide synthase; ET: endothelin; ECE: endothelin converting enzyme; COX: cyclooxygenase; PG: prostaglandin; IL: interleukin; TNF: tumour necrosis factor.

$\mathrm{PGI}_{2}$, leukotrienes (LTs), endothelins (ETs), and plateletactivating factor (PAF) [24]. During lung injury, the pulmonary circulation is exposed to the widespread release of these constricting and dilating mediators, the net effect is an increase in the vascular tone. Inhibitors of COX $[25,26]$ and of NO synthesis or their effects, have been shown to further increase $P$ pa in experimental lung injury [27]. Intravenous infusion of endotoxin in sheep causes $P$ pa to rise within several minutes, which remains raised for hours [28]. Furthermore, endotoxin infusion causes an increase in the levels of PAF [29]. Pretreatment with PAF antagonists inhibits both the rise in $\mathrm{TXA}_{2}$ and the pulmonary pressor response to endotoxin [30].

\section{Cyclooxygenase metabolism}

Arachidonic acid is the precursor of a variety of vasoactive and inflammatory mediators implicated in the pathogenesis of 
$\mathrm{PH}$ in ARDS. Arachidonic acid is liberated from membrane phospholipids by phospholipase $\mathrm{A}_{2}$, and is subsequently metabolised by either COX, to form $\mathrm{PGI}_{2}$ and $\mathrm{TXA}_{2}$, or lipoxygenase, to form LTs. $\mathrm{PGI}_{2}$ is a potent vasodilator, whereas $\mathrm{TXA}_{2}$ is a potent vasoconstrictor. The balance between the release of these two prostanoids therefore contributes to pulmonary vascular tone [31]. Endothelial cells mainly form $\mathrm{PGI}_{2}$, whereas platelets and to a lesser extent neutrophils, are the main sources of $\mathrm{TXA}_{2}$. However, as neither neutrophil [32] nor platelet [33] depletion have been shown to abolish PH completely in experimental ARDS, it is likely that other possible sources of $\mathrm{TXA}_{2}$ (e.g. endothelium, macrophages, eosinophils) contribute. In animal models, serum levels of $\mathrm{TXB}_{2}$, the product of $\mathrm{TXA}_{2}$ metabolism, rose concurrently with $P$ pa. Further, pretreatment with $\mathrm{COX}$ inhibitors prevented the release of $\mathrm{TXA}_{2}$ [34] and attenuated the rise in $P$ pa [35]. Clinical studies in patients with ARDS have shown increased levels of circulating $\mathrm{TXA}_{2}$ in bronchoalveolar lavage fluid (BALF) [36]. TXA 2 has also been shown to initiate the microvascular thrombosis that is responsible for perfusion abnormalities and recurrent ischaemia-reperfusion injury to the lung. Similarly, the vasoconstrictive effects of $\mathrm{TXA}_{2}$ contribute to impaired gas exchange [31], however, these are probably not the sole mediators of PH in lung injury as dazoxiben, a specific TXA-synthase inhibitor, does not alter $P$ pa in patients with ARDS [36]. Additionally, COX inhibitors block the acute $\mathrm{PH}$ associated with endotoxin infusion, but fail to prevent the rise in $P$ pa that occurs several hours later. Likewise, in animal models of lung injury, TXA synthase inhibition decreased pulmonary oedema formation and inhibited microembolism, but only partially reduced $\mathrm{PH}$ [37]. In these circumstances, arachidonic acid metabolism may be shunted towards the lipoxygenase pathway, resulting in increased release of LTs [38].

\section{Lipoxygenase metabolism}

LTs are derived from arachidonic acid by 5-lipoxygenase. $\mathrm{LTB}_{4}$ is a potent neutrophil chemokine, whilst $\mathrm{LTC}_{4}$ and $\mathrm{LTD}_{4}$ cause pulmonary vasoconstriction, increased capillary permeability and pulmonary oedema formation. Clinical studies have demonstrated that increased levels of LTs have been found in the BALF taken from patients with ARDS [39]. It has also been shown that 5-lipoxygenase metabolites were elevated in BALF from sheep challenged with endotoxin [40, 41]. However, the acute pulmonary hypertensive response to endotoxin infusion is only partially inhibited by 5-lipoxygenase inhibitors [40, 41] or by LT antagonists [42-44]. Ketoconazole is an imidazole antifungal agent that inhibits TXA synthase and 5-lipoxygenase without inhibiting COX. Therefore, it may have a dual anti-inflammatory action in ARDS, through the inhibition of inflammatory eicosanoid synthesis, thereby directing COX products down other, less inflammatory paths e.g. those synthesising $\mathrm{PGI}_{2}$ or $\mathrm{PGE}_{1}$ [45]. In four trials using enteric ketoconazole to treat patients at risk of developing, or with established ARDS, a reduction in the incidence of acute respiratory failure in high-risk surgical patients and other critically ill patients was found [46-48]. By contrast, in patients with established ARDS, no differences were found regarding in-hospital mortality, or markers of gas exchange between the ketoconazole and placebo groups [49].

\section{Endothelins}

The release of ETs may also contribute to the pulmonary vasoconstrictor response. ET-1, a 21 amino-acid peptide, is formed from big ET-1 by the action of membrane bound metalloproteases called ET-converting enzyme [50]. ET-1 is both a potent vasoconstrictor and a comitogen/proliferation factor for vascular smooth muscle [51], and has been implicated in the pathogenesis of PH [52]. Although the main source of ET-1 is considered to be the endothelium [50], many cell types have been shown to release this peptide in vitro, including vascular smooth muscle, cultured from systemic vessels [53]. However, it is unclear whether ET-1 has a primary pathogenetic role or whether it is a secondary mediator that perpetuates the inflammatory response in ARDS. ET expression is upregulated in lung tissue from patients with PH [54]. Increased circulating levels of ET-1 have been detected in patients with ARDS. A comparison of the vasopressor response to ET-1 infusion in the ARDS group with that of healthy controls suggested that the increased circulating levels were due to both reduced clearance and net ET-1 release by the pulmonary circulation [55]. An autocrine role for ET-1 in human pulmonary artery smooth muscle was recently postulated, with important implications for the pathogenesis of human pulmonary vascular remodelling in ARDS of prolonged duration [51].

\section{Pulmonary vascular remodelling in acute respiratory distress syndrome}

Early in the course of ARDS, pulmonary vasoconstriction, thromboembolism and interstitial oedema, all of which are potentially reversible, act together to elevate pulmonary vascular resistance (PVR). In the subacute and chronic phases of ARDS, fibrocellular intimal proliferation occurs, involving predominantly small muscular arteries, but also veins and lymphatics (table 2) [3]. Here, the vascular lumens are compromised by concentric arrangements of fibrin, myointimal and hyperplastic endothelial cells, mucopolysaccharides, and collagen. This proliferation is considered to represent the sequelae of endothelial injury and repair, it is a significant contributor to the reduction of the vascular luminal area and reduces background filling on pulmonary angiographs

Table 2. - Spectrum of pulmonary vascular dysfunction in acute respiratory distress syndrome

\begin{tabular}{lll}
\hline Target & \multicolumn{1}{c}{ Mechanism } & \multicolumn{1}{c}{ Consequence } \\
\hline Resistance vessel & $\begin{array}{l}\text { Dysregulated vasodilatation/ } \\
\text { vasoconstriction }\end{array}$ & $\begin{array}{l}\text { Pulmonary hypertension } \\
\text { Ventilation/perfusion mismatch } \\
\text { Loss of hypoxic pulmonary vasoconstriction } \\
\text { Increased permeability/oedema } \\
\text { Microvasculature }\end{array}$ \\
& Endothelial inflammation & $\begin{array}{l}\text { Leukocyte activation and tissue invasion } \\
\text { Intravascular thrombosis }\end{array}$ \\
& Extravascular compression & $\begin{array}{l}\text { Increased dead space } \\
\text { Pulmonary hypertension }\end{array}$ \\
& & Increased permeability/oedema \\
Postcapillary venule & Increased permeability/oedema
\end{tabular}


performed post mortem. Obstruction of venous and lymphatic channels further increases intracapillary pressure, contributing to the accumulation of interstitial oedema fluid, as well as impeding its removal from the lung [3]. In the late, fibroproliferative phases of ARDS, more permanent structural changes consequent on vascular remodelling of the pulmonary vasculature, with medial hypertrophy and a reduction in luminal diameter contribute to PH [3]. The thickness of the media relative to the vascular diameter increases, which correlates with the extent of parenchymal honeycombing and haemorrhage [56]. Arterial tortuosity occurs as a result of distortion by irregular contracting fibrous tissue. The increased anatomical concentration of pulmonary blood vessels measured in patients in the late stage of ARDS has been suggested to reflect the combined effects of abnormal dilatation, tortuosity and crowding of vessels, rather than a restoration or regrowth of normal arteries [3].

\section{Thromboembolism in acute respiratory distress syndrome}

Post mortem studies have shown that thromboemboli are the most consistently observed vascular lesions in patients with ARDS and are present in $95 \%$ of cases [3]. These may be either embolic, or formed in situ. In ARDS it is likely that both mechanisms of clot deposition occur. Macrothrombi (in arteries $>1 \mathrm{~mm}$ in diameter) are found in as many as $86 \%$ of patients through post mortem examination or angiography and are more prevalent in patients who die in the early phases of the syndrome [3]. Moreover, the number of macrothrombi, have been shown to correlate with the number of filling defects seen on ante mortem angiographs [3, 57]. Microthrombi, which have a similar prevalance to macrothrombi, contribute to the reduction in peripheral arterial fillings on post mortem pulmonary angiograms and are distributed throughout all phases of ARDS [3].

\section{Therapy for pulmonary hypotension in acute respiratory distress syndrome}

\section{Intravenous vasodilators}

If cardiac function is limited as a result of increased right ventricular afterload, reductions in PVR may prove therapeutically beneficial. Endogenous vasodilators released as part of the inflammatory process modulate the increase in $P$ pa, but contribute to the deterioration in gas exchange, presumably by dilating vessels in hypoxic lung regions (i.e. inhibiting HPV) [19]. Blockade of COX and NO have been shown to improve $\mathrm{Pa}, \mathrm{O}_{2}$ by reducing intrapulmonary shunt in animals with oleic acid-induced pulmonary oedema [19, 25-27]. In clinical practice, several intravenous vasodilators have been administered in patients with ARDS, with the aim of increasing cardiac output and hence oxygen delivery. However, intravenous vasodilators have two drawbacks that limit their therapeutic utility. Most lack selectivity for the pulmonary circulation, and may therefore cause systemic hypotension. Secondly, intravenous vasodilators act on all pulmonary vessels, in both ventilated and nonventilated areas. The net effect is to increase shunt fraction, which leads to a deterioration in oxygenation $[58,59]$.

\section{Prostaglandin $E_{1}$}

$\mathrm{PGE}_{1}$ is a prostanoid vasodilator, which inhibits platelet aggregation, impairs neutrophil chemotaxis and release of toxic products, and decreases macrophage activation. In one large-scale, randomised, controlled trial, $\mathrm{PGE}_{1}$ reduced $P$ pa and increased cardiac output in patients with ARDS, indicating unequivocal pulmonary vasodilation. However, $\mathrm{Pa}, \mathrm{O}_{2}$ decreased by $22 \%$ as the result of an increase in true shunt from $21 \%$ to $35 \%$ [60]. Further, $\mathrm{PGE}_{1}$ has not been shown to afford a survival benefit in ARDS, despite significantly reducing PVR [6]. The potentially adverse effects of $\mathrm{PGE}_{1}$ on systemic blood pressure, cardiac rhythm, and gas exchange therefore limit its use as a pulmonary vasodilator in ARDS.

\section{Intravenous prostaglandin $\mathrm{I}_{2}$}

$\mathrm{PGI}_{2}$ is an endothelium-derived prostanoid vasodilator that also inhibits platelet aggregation and neutrophil adhesion. Epoprostenol, a synthetic analogue of $\mathrm{PGI}_{2}$, has recently been shown to improve survival in patients with primary pulmonary hypertension (PPH) [61]. This is probably through its properties as a selective vasodilator [62] and more speculatively by its ability to reverse vascular remodelling and platelet adhesion [63]. However, in patients with ARDS, intravenous $\mathrm{PGI}_{2}$ led to an increase in intrapulmonary shunting, a deterioration in oxygenation, and systemic hypotension despite its reduction of $P$ pa [64]. The side-effect profile of prostacyclin therapy, therefore limits its use as a pulmonary vasodilator in ARDS.

\section{Other intravenous vasodilators}

Increases in shunt have also been reported in patients with ARDS after the administration of other intravenous vasodilators, including nitroprusside [65], isoproterenol, and diltiazem [17].

\section{Inhaled vasodilators}

Vasodilators administered into the respiratory tract by inhalation, only access ventilated alveoli. Drug delivery by this route is therefore theoretically attractive, since recruitment of pulmonary blood flow to ventilated lung units improves $V^{\prime} / Q^{\prime}$ matching and therefore arterial oxygenation; in addition $P$ pa is reduced $[66,67]$. Directly accessing the pulmonary circulation by inhalation also tends to limit the systemic effects of vasodilators (table 3 ).

\section{Inhaled nitric oxide}

NO is a ubiquitous biological mediator implicated in modulating vascular resistance [68]. Interestingly however, the concentration of NO in exhaled air is lower in patients with ARDS compared with controls, despite the marked alveolar inflammation that is characteristic of the syndrome [69]. Various isoforms of NO synthase convert L-arginine to

Table 3. - Comparison of the theoretical effects of a putative short acting vasodilator, administered intravenously or by inhalation

\begin{tabular}{lcc}
\hline & Intravenous & Inhaled \\
\hline Systemic blood pressure & Decreased & Unchanged \\
Intrapulmonary shunt & Increased & Decreased \\
\hline
\end{tabular}

\#: the effects on the systemic circulation will be influenced by the site of intravenous administration (i.e. peripheral venous versus pulmonary artery) and the duration of action the drug has in circulation. 
L-citrulline and NO in the presence of oxygen and several cofactors [70]. Once produced, NO is freely diffusible and enters the pulmonary smooth muscle cells to activate soluble guanylate cyclase and produce guanosine 3,5-cyclic monophosphate (cGMP) [70]. NO is rapidly inactivated by avid binding to haemoglobin, thus reducing its vasoactive half-life to milliseconds and obviating the possibility of systemic vasodilation.

In animal models, inhaled NO at concentrations of 5-80 parts per million ( $\mathrm{ppm}$ ) has been shown to produce selective and rapidly reversible pulmonary vasodilation [71, 72], and in appropriate models, to improve $V^{\prime} / Q^{\prime}$ matching and increase arterial oxygenation [73-75]. Furthermore in experimental preparations, inhaled NO decreases both pulmonary oedema formation and neutrophil sequestration in the lung [75, 76]. The response to inhaled NO in a porcine model of early ARDS has been shown to depend on the pre-existing distribution of pulmonary blood flow, being most beneficial in septic animals with a large intrapulmonary shunt [13]. However, as ARDS evolved, this benefit was lost with impaired diffusion of NO into the pulmonary circulation [77].

In 1993, in patients with ARDS, 18 ppm inhaled NO was shown to induce small but significant decrements in mean $P$ pa, PVR and shunt fraction, without affecting cardiac output or systemic blood pressure. Oxygenation improved significantly over the population as a whole, although individual responsiveness was variable. NO was inhaled for 3-53 days without loss of beneficial haemodynamic effect or evidence of toxicity [64]. In subsequent studies, NO was shown to increase the $\mathrm{Pa}, \mathrm{O}_{2} / \mathrm{FI}, \mathrm{O}_{2}$ ratio, decrease the pulmonary shunt fraction and reduce PVR $[60,66]$. Doses that improved gas exchange $(0.06-0.25 \mathrm{ppm})$, were found to be lower than the doses that reduced $P$ pa $(5-20 \mathrm{ppm})$.

However, the results of two multicentre, randomised, controlled trials comparing inhaled NO with conventional therapy in ARDS failed to show a mortality benefit of this therapy (table 4) [78, 79]. In a total of 177 ARDS patients at 30 centres, an acute increase in $\mathrm{Pa}, \mathrm{O}_{2}$ was observed in $60 \%$ of the patients receiving NO, compared with $24 \%$ of those exposed to placebo. This improvement in oxygenation resulted in a decrease in the intensity of mechanical ventilation over the first 4 days which was not sustained thereafter. There were no differences between the groups in terms of overall mortality, the number of days alive off mechanical ventilation, or the number of days alive meeting the oxygen requirement for extubation [78]. A second, European multicentre (43 sites) trial, which enrolled 260 medical and surgical patients with ARDS known to respond favourably to NO, revealed a 30 day mortality of $45 \%$ for treated patients, compared with $38 \%$ for controls [79]. The mortality rate in those not responding to NO (and therefore not randomised) was also 45\%. After huge enthusiasm for and widespread use of this therapeutic strategy, the results of these studies clearly fail to support the routine use of inhaled NO in the treatment of patients with ARDS. Furthermore, it is difficult to predict which patients will respond to inhaled NO or not [69]. Methaemoglobinaemia decreased platelet aggregation and, when abruptly discontinued, rebound deterioration in arterial oxygenation and elevation of PH were also significant possible side-effects [60, 66]. Finally, it has been demonstrated that any benefit in oxygenation does not last longer than $24 \mathrm{~h}$ (table 4) [80, 81].

\section{Inhaled (nebulised) prostaglandin $I_{2}$}

Nebulised $\mathrm{PGI}_{2}$, which acts through an increase in the level of the second messenger intracellular cyclic adenosine monophosphate (cAMP), has been evaluated as an inhaled pulmonary vasodilator. In contrast to $\mathrm{NO}$, nebulised $\mathrm{PGI}_{2}$ does not require sophisticated equipment for its administration. In small-scale studies, nebulised $\mathrm{PGI}_{2}$ induced selective pulmonary vasodilation and redistributed blood flow from areas of shunt to well-ventilated regions, thereby improving $\mathrm{Pa}, \mathrm{O}_{2} /$ $F \mathrm{I}, \mathrm{O}_{2}$ ratio $[82,83]$. These studies demonstrated decreases in $P$ pa to those seen with inhaled NO $[82,83]$, but cardiac output and right ventricular function remained unchanged [83]. However, $\mathrm{PGI}_{2}$, like NO, has not been shown to improve survival in ARDS patients. Moreover, the sustained physiological improvement has been modest in many studies [64, 84]. Recent therapeutic strategies in PPH have reported significant benefits with oral $\mathrm{PGI}_{2}$ analogues [85], but evidence for their use in ARDS is lacking.

\section{Almitrene bismesylate}

Further attempts to manipulate pulmonary vascular tone with the purpose of improving gas exchange have been made by administrating a combination of drugs that augment HPV with inhaled NO. The use of pulmonary vasoconstrictors in patients with ARDS can lead to improved gas exchange if HPV is restored. However, they are superficially unattractive because of their negative effect on $P$ pa and right ventricular function. In these circumstances, constricting the shunting vascular bed whilst simultaneously vasodilating well-ventilated areas would be therapeutically attractive [86-88]. Almitrine, a peripheral chemoreceptor agonist, improves $V^{\prime} / Q^{\prime}$ matching in patients with chronic obstructive pulmonary disease, presumably through an enhancement of HPV [89]. Recently, almitrine has been shown to improve gas exchange in patients with ARDS without decreasing cardiac output, despite increasing

Table 4.-Randomised controlled trials of inhaled nitric oxide (NO) in patients with acuterespiratory distress syndrome

\begin{tabular}{|c|c|c|c|c|}
\hline $\begin{array}{l}\text { First author } \\
\text { [ref.] }\end{array}$ & $\begin{array}{l}\text { Patients } \\
n\end{array}$ & $\begin{array}{l}\text { Inhaled NO } \\
\text { dose ppm }\end{array}$ & $\begin{array}{l}\text { Duration } \\
\text { days }\end{array}$ & Outcome \\
\hline LUNDIN [79] & 260 & $2-40$ & 30 & $\begin{array}{l}\text { Development of severe respiratory failure less }(2.2 \% \text { versus } 10.3 \%) \text { in } \\
\text { NO treated group. Mortality not altered ( } 44 \% \text { versus } 40 \% \text { control). }\end{array}$ \\
\hline DELLINGER [78] & 177 & $1.25-80$ & 28 & $\begin{array}{l}P \mathrm{a}, \mathrm{O}_{2} \text { increased }>20 \% \text { in first } 4 \mathrm{~h} \text { in } 60 \% \text { of patients treated with NO } \\
\text { and } 24 \% \text { of controls. } \mathrm{FI}, \mathrm{O}_{2} \text { and intensity of ventilation could be reduced } \\
\text { in first } 4 \text { days. No difference in mortality ( } 30 \% \text { versus } 32-38 \% \text { in } \\
\text { NO-treated groups). }\end{array}$ \\
\hline MICHAEL [80] & 40 & $5-20$ & 3 & $\begin{array}{l}\text { NO improved } \mathrm{Pa}, \mathrm{O}_{2} / F \mathrm{I}, \mathrm{O}_{2} \text { by at least } 20 \% \text { and allowed a decrease } \\
\text { in } F \mathrm{I}, \mathrm{O}_{2} \text { of at least } 0.15 \text { only in the first } 24 \mathrm{~h} \text { in more treated patients } \\
\text { than controls. }\end{array}$ \\
\hline TRONCY [81] & 30 & $0.5-40$ & 30 & $\begin{array}{l}\text { NO improved oxygenation, only in the first } 24 \mathrm{~h} \text { in more treated } \\
\text { patients than controls. Mortality ( } 60 \% \text { versus } 67 \% \text { in control) not altered. }\end{array}$ \\
\hline
\end{tabular}

ppm: parts per million; $F \mathrm{I}, \mathrm{O}_{2}$ :inspiratory oxygen fraction; $\mathrm{Pa}_{\mathrm{a}} \mathrm{O}_{2}$ : arterial oxygen tension. 
right ventricular afterload [90]. Further, the combination of almitrine with inhaled NO had additive effects on arterial oxygenation, with no increase in $P$ pa [67]. One study found that the administration of $\mathrm{NO}$ or almitrine increased $\mathrm{Pa}, \mathrm{O}_{2}$ by 9.9 and $13.4 \mathrm{kPa}(75$ and $101 \mathrm{mmHg})$ respectively, but by $23.3 \mathrm{kPa}(175 \mathrm{mmHg})$ after administration of both [88]. In a further series of 17 patients, NO caused a modest, but nonsignificant improvement in $\mathrm{Pa}, \mathrm{O}_{2} / F \mathrm{I}, \mathrm{O}_{2}$ ratio from $11.7 \pm 3.9$ to $13.0 \pm 4.9 \mathrm{kPa}(88 \pm 30$ to $98 \pm 37 \mathrm{mmHg})$, whereas the combination of $\mathrm{NO}$ and almitrine caused a significant increase in the $\mathrm{Pa}, \mathrm{O}_{2} / F \mathrm{I}, \mathrm{O}_{2}$ ratio from $12.2 \pm 3.3$ to $17.29 \pm 7.4 \mathrm{kPa}(92 \pm 25$ to $130 \pm 56 \mathrm{mmHg}$ ) [91]. Combined therapy also caused a significant decrease in the $P$ pa, similar to that induced by inhaled NO alone. It therefore appears that almitrine improves oxygenation and augments the effects of inhaled NO. However, its effects to date have only been determined in nonrandomised trials. Further studies are required prior to almitrine being a recommended form of therapy.

\section{Oral vasodilators and antiproliferative agents}

\section{Endothelin-receptor antagonists}

Recent therapeutic strategies in PPH have reported significant benefits from the administration of an oral ET-receptor antagonist, bosentan [92]. Small, but beneficial effects, in exercise capacity were demonstrated in a trial involving 213 patients, suggesting that ET-receptor blockade has a therapeutic role in some patients with PPH. However, the duration of the 16-week trial was insufficient to test for a difference in mortality, and there was an increased incidence of hepatic dysfunction at a higher dose of ET-receptor blockade. Evidence for supporting its application in ARDS is presently lacking.

\section{Sildenafil}

The use of sildenafil, a phosphodiesterase type-5 inhibitor, has recently been reported in 16 patients with PH secondary to lung fibrosis [93], in which it was shown to be a more selective pulmonary vasodilator than $\mathrm{PGI}_{2}$. However, unlike $\mathrm{NO}$, systemic blood pressure fell in patients who received sildenafil but not inhaled NO. At present, there is no evidence to support the use of sildenafil in patients with ARDS. However, by inhibiting phosphodiesterase type 5, sildenafil stabilises cGMP (the second messenger of NO), unlike prostacyclins, that act through an increase in cAMP. Clinical studies are therefore needed to assess the potential additive effects of simultaneous increase in cGMP and cAMP by combining these two classes of drugs.

\section{Summary}

Pulmonary hypertension appears to be a ubiquitous complication of acute respiratory distress syndrome. Pulmonary hypertension contributes to impaired right ventricular performance, reduced cardiac output and is associated with an increase in the mortality. Pharmacological manipulation of pulmonary vascular tone is feasible in patients with acute respiratory distress syndrome, but without a proven mortality benefit. The properties of the ideal pulmonary vasodilator include selectivity for the pulmonary circulation, no impairment in hypoxic pulmonary vasoconstriction, ease of administration, and lack of adverse systemic effects. Research aimed at further elucidating the mechanisms underlying pulmonary hypertension in acute respiratory distress syndrome can be expected to provide improvements in the results of pharmacological interventions. Furthermore, the incorporation of new treatments into the armamentarium should be based on the results from well-designed and carefully performed clinical trials that demonstrate convincing evidence of both safety and efficacy.

\section{References}

1. Bernard GR, Artigas A, Brigham KL, et al. The AmericanEuropean Consensus Conference on ARDS. Definitions, mechanisms, relevant outcomes, and clinical trial coordination. Am J Respir Crit Care Med 1994; 149: 818-824.

2. Zapol WM, Snider MT. Pulmonary hypertension in severe acute respiratory failure. $N$ Engl J Med 1977; 296: 476-480.

3. Tomashefski JF Jr, Davies P, Boggis C, Greene R, Zapol WM, Reid LM. The pulmonary vascular lesions of the adult respiratory distress syndrome. Am J Pathol 1983; 112: 112-126.

4. Murray JF, Matthay MA, Luce JM, Flick MR. An expanded definition of the adult respiratory distress syndrome. Am Rev Respir Dis 1988; 138: 720-723.

5. Bernard GR, Luce JM, Sprung CL, et al. High-dose corticosteroids in patients with the adult respiratory distress syndrome. N Engl J Med 1987; 317: 1565-1570.

6. Bone RC, Slotman G, Maunder R, et al. Randomized double-blind, multicenter study of prostaglandin E1 in patients with the adult respiratory distress syndrome. Prostaglandin E1 Study Group. Chest 1989; 96: 114-119.

7. Sloane PJ, Gee MH, Gottlieb JE, et al. A multicenter registry of patients with acute respiratory distress syndrome. Am Rev Respir Dis 1992; 146: 419-426.

8. Suchyta MR, Clemmer TP, Elliott CG, Orme JF Jr, Weaver LK. The adult respiratory distress syndrome. A report of survival and modifying factors. Chest 1992; 101: 1074-1079.

9. Sibbald WJ, Driedger AA. Right ventricular function in acute disease states: pathophysiologic considerations. Crit Care Med 1983; 11: 339-345.

10. Prewitt RM, McCarthy J, Wood LD. Treatment of acute low pressure pulmonary edema in dogs: relative effects of hydrostatic and oncotic pressure, nitroprusside, and positive end-expiratory pressure. J Clin Invest 1981; 67: 409-418.

11. Sibbald WJ, Paterson NA, Holliday RL, Anderson RA, Lobb TR, Duff JH. Pulmonary hypertension in sepsis: measurement by the pulmonary arterial diastolic-pulmonary wedge pressure gradient and the influence of passive and active factors. Chest 1978; 73: 583-591.

12. Schuster DP. ARDS: clinical lessons from the oleic acid model of acute lung injury. Am J Respir Crit Care Med 1994; 149: 245-260.

13. Gust R, McCarthy TJ, Kozlowski J, Stephenson AH, Schuster DP. Response to inhaled nitric oxide in acute lung injury depends on distribution of pulmonary blood flow prior to its administration. Am J Respir Crit Care Med 1999; 159: $563-570$

14. Dantzker DR, Brook CJ, Dehart P, Lynch JP, Weg JG. Ventilation-perfusion distributions in the adult respiratory distress syndrome. Am Rev Respir Dis 1979; 120: 1039-1052.

15. Melot C, Naeije R, Mois P, Hallemens R, Lejeune $\mathrm{P}$, Jaspar N. Pulmonary vascular tone improves pulmonary gas exchange in the adult respiratory distress syndrome. Am Rev Respir Dis 1987; 136: 1232-1236.

16. Grant BJ, Davies EE, Jones HA, Hughes JM. Local regulation of pulmonary blood flow and ventilationperfusion ratios in the coatimundi. J Appl Physiol 1976; 40: 216-228.

17. Melot C, Naeije R, Hallemans R, Lejeune P, Mols P. Hypoxic pulmonary vasoconstriction and pulmonary gas exchange in normal man. Respir Physiol 1987; 68: 11-27.

18. Brimioulle S, Lejeune P, Naeije R. Effects of hypoxic 
pulmonary vasoconstriction on pulmonary gas exchange J Appl Physiol 1996; 81: 1535-1543.

19. Leeman M, Delcroix M, Vachiery JL, Melot C, Naeije R Blunted hypoxic vasoconstriction in oleic acid lung injury: effects of cyclooxygenase inhibitors. $J$ Appl Physiol 1992; 72: 251-258.

20. Archer SL, Weir EK, Reeve HL, Michelakis E. Molecular identification of $\mathrm{O} 2$ sensors and $\mathrm{O} 2$-sensitive potassium channels in the pulmonary circulation. Adv Exp Med Biol 2000; 475: 219-240.

21. Liu SF, Crawley DE, Barnes PJ, Evans TW. Endotheliumderived relaxing factor inhibits hypoxic pulmonary vasoconstriction in rats. Am Rev Respir Dis 1991; 143: 32-37.

22. Brimioulle S, Julien V, Gust R, Kozlowski JK, Naeije E, Schuster DP. Importance of hypoxic vasoconstriction in maintaining oxygenation during acute lung injury. Crit Care Med 2002; 30: 874-880.

23. Leeman M, Lejeune P, Closset J, Vachiery JL, Melot C, Naeije R. Nature of pulmonary hypertension in canine oleic acid pulmonary edema. J Appl Physiol 1990; 69: 293-298.

24. Repine JE. Scientific perspectives on adult respiratory distress syndrome. Lancet 1992; 339: 466-469.

25. Leeman M, Lejeune P, Hallemans R, Melot C, Naeije R. Effects of increased pulmonary vascular tone on gas exchange in canine oleic acid pulmonary edema. $J$ Appl Physiol 1988; 65: 662-668.

26. Schulman LL, Lennon PF, Ratner SJ, Enson Y. Meclofenamate enhances blood oxygenation in acute oleic acid lung injury. J Appl Physiol 1988; 64: 710-718.

27. Leeman M, De Beyl VZ, Gilbert E, Melot C, Naeije R. Is nitric oxide released in oleic acid lung injury? J Appl Physiol 1993; 74: 650-654.

28. Esbenshade AM, Newman JH, Lams PM, Jolles PH, Brigham KL. Respiratory failure after endotoxin infusion in sheep: lung mechanics and lung fluid balance. $J \mathrm{Appl}$ Physiol 1982; 53: 967-976.

29. Doebber TW, Wu MS, Robbins JC, Choy BM, Chang MN, Shen TY. Platelet activating factor (PAF) involvement in endotoxin-induced hypotension in rats. Studies with PAFreceptor antagonist kadsurenone. Biochem Biophys Res Commun 1985; 127: 799-808.

30. Christman BW, Lefferts PL, Blair IA, Snapper JR. Effect of platelet-activating factor antagonism on endotoxin-induced lung dysfunction in awake sheep. Am Rev Respir Dis 1990; 142: $1272-1278$.

31. Petrak RA, Balk RA, Bone RC. Prostaglandins, cyclooxygenase inhibitors, and thromboxane synthase inhibitors in the pathogenesis of multiple systems organ failure. Crit Care Clin 1989; 5: 303-314.

32. Hinson JM, Hutchinson AA, Ogletree ML, Brigham KL, Snapper JR. Effect of granulocyte depletion on altered lung mechanics after endotoxemia in sheep. J Appl Physiol 1983; 55: 92-99.

33. Snapper JR, Hinson JM, Hutchinson AA, Lefferts PL, Ogletree ML, Brigham KL. Effects of platelet depletion on the unanaesthetized sheep's pulmonary response to endotoxemia. J Clin Invest 1984; 74: 1782-1791.

34. Winn R, Harlan J, Nadir B, Harker L, Hildebrandt J. Thromboxane A2 mediates lung vasoconstriction but not permeability after endotoxin. J Clin Invest 1983; 72: 911-918.

35. Begley CJ, Ogletree ML, Meyrick BO, Brigham KL. Modification of pulmonary responses to endotoxemia in awake sheep by steroidal and nonsteroidal anti-inflammatory agents. Am Rev Respir Dis 1984; 130: 1140-1146.

36. Leeman M, Boeynaems JM, Degaute JP, Vincent JL, Kahn RJ. Administration of dazoxiben, a selective thromboxane synthetase inhibitor, in the adult respiratory distress syndrome. Chest 1985; 87: 726-730.

37. Hetchman HB, Valeri CR, Shepro D. Role of humoral mediators in adult respiratory distress syndrome. Chest 1984; 86: 623-627.

38. Ogletree ML, Brigham KL. Effects of cyclooxygenase inhibitors on pulmonary vascular responses to endotoxin in unanesthetized sheep. Prostaglandins Leukot Med 1982; 8: 489-502.

39. Matthay MA, Eschenbacher WL, Goetzl EJ. Elevated concentrations of leukotriene D4 in pulmonary edema fluid of patients with the adult respiratory distress syndrome. J Clin Immunol 1984; 4: 479-483.

40. Coggeshall JW, Christman BW, Lefferts PL, et al. Effect of inhibition of 5-lipoxygenase metabolism of arachidonic acid on response to endotoxemia in sheep. J Appl Physiol 1988; 65: $1351-1359$.

41. Olson NC, Dobrowsky RT, Fleisher LN. Hydroxyeicosatetraenoic acids are increased in bronchoalveolar lavage fluid of endotoxemic pigs. Prostaglandins 1987; 34: 493-503.

42. Ahmed T, Wasserman MA, Muccitelli R, Tucker S, Gazeroglu H, Marchette B. Endotoxin-induced changes in pulmonary hemodynamics and respiratory mechanics. Role of lipoxygenase and cyclooxygenase products. Am Rev Respir Dis 1986; 134: 1149-1157.

43. Ahmed T, Weichman B, Wasserman MA, Muccitelli R, Tucker S, Marchette B. Prevention and reversal of endotoxininduced pulmonary hypertension by a leukotriene antagonist. Eur Respir J 1988; 1: 145-152.

44. Gross D, Ben Dahan J, Landau EH, Krausz MM. Effect of leukotriene inhibitor LY-171883 on the pulmonary response to Escherichia coli endotoxemia. Crit Care Med 1990; 18: 190-197.

45. Beetens JR, Loots W, Somers Y, Coene MC, De Clerck F. Ketoconazole inhibits the biosynthesis of leukotrienes in vitro and in vivo. Biochem Pharmacol 1986; 35: 883-891.

46. Slotman GJ, Burchard KW, D'Arezzo A, Gann DS. Ketoconazole prevents acute respiratory failure in critically ill surgical patients. J Trauma 1988; 28: 648-654.

47. Yu M, Tomasa G. A double-blind, prospective, randomized trial of ketoconazole, a thromboxane synthetase inhibitor, in the prophylaxis of the adult respiratory distress syndrome. Crit Care Med 1993; 21: 1635-1642.

48. Sinuff T, Cook DJ, Peterson JC, Fuller HD. Development, implementation, and evaluation of a ketoconazole practice guideline for ARDS prophylaxis. J Crit Care 1999; 14: 1-6.

49. Network TA. Ketoconazole for early treatment of acute lung injury and acute respiratory distress syndrome: a randomized controlled trial. The ARDS Network. JAMA 2000; 283: 1995-2002.

50. Yanagisawa M, Kurihara H, Kimura S, et al. A novel potent vasoconstrictor peptide produced by vascular endothelial cells. Nature 1988; 332: 411-415.

51. Wort SJ, Woods M, Warner TD, Evans TW, Mitchell JA. Endogenously released endothelin-1 from human pulmonary artery smooth muscle promotes cellular proliferation relevance to pathogenesis of pulmonary hypertension and vascular remodeling. Am J Respir Cell Mol Biol 2001; 25: 104-110.

52. MacLean MR. Endothelin-1: a mediator of pulmonary hypertension? Pulm Pharmacol Ther 1998; 11: 125-132.

53. Woods M, Mitchell JA, Wood EG, et al. Endothelin-1 is induced by cytokines in human vascular smooth muscle cells: evidence for intracellular endothelin-converting enzyme. $\mathrm{Mol}$ Pharmacol 1999; 55: 902-909.

54. Giaid A, Yanagisawa M, Langleben D, et al. Expression of endothelin-1 in the lungs of patients with pulmonary hypertension. N Engl J Med 1993; 328: 1732-1739.

55. Druml W, Steltzer H, Waldhausl W, et al. Endothelin-1 in adult respiratory distress syndrome. Am Rev Respir Dis 1993; 148: 1169-1173.

56. Barth PJ, Knoch M, Muller E, Sangmeister C, Bittinger A. Morphometry of parenchymal and vascular alterations in ARDS after extracorporeal carbon dioxide removal therapy. Pathol Res Pract 1992; 188: 653-656.

57. Greene R, Zapol WM, Snider MT, et al. Early bedside detection of pulmonary vascular occlusion during acute respiratory failure. Am Rev Respir Dis 1981; 124: 593-601. 
58. Leeman M. The pulmonary circulation in acute lung injury: a review of some recent advances. Intensive Care Med 1991; 17: 254-260.

59. Pierpont G, Hale KA, Franciosa JA, Cohn JN. Effects of vasodilators on pulmonary haemodynamics and gas exchange in left ventricular failure. Am Heart J 1980; 99: 208-216.

60. Melot C, Lejeune P, Leeman M, Moraine JJ, Naeije R. Prostaglandin E1 in the adult respiratory distress syndrome. Benefit for pulmonary hypertension and cost for pulmonary gas exchange. Am Rev Respir Dis 1989; 139: 106-110.

61. Barst RJ, Rubin LJ, Long WA, et al. A comparison of continuous intravenous epoprostenol (prostacyclin) with conventional therapy for primary pulmonary hypertension. The Primary Pulmonary Hypertension Study Group. N Engl J Med 1996; 334: 296-302.

62. McLaughlin VV, Genthner DE, Panella MM, Rich S. Reduction in pulmonary vascular resistance with long-term epoprostenol (prostacyclin) therapy in primary pulmonary hypertension. N Engl J Med 1998; 338: 273-277.

63. Wort SJ, Mitchell JA, Woods M, Evans TW, Warner TD. The prostacyclin-mimetic cicaprost inhibits endogenous endothelin-1 release from human pulmonary artery smooth muscle cells. J Cardiovasc Pharmacol 2000; 36: S410-S413.

64. Rossaint R, Falke KJ, Lopez F, Slama K, Pison U, Zapol WM. Inhaled nitric oxide for the adult respiratory distress syndrome. N Engl J Med 1993; 328: 399-405.

65. Radermacher P, Huet Y, Pluskwa F, et al. Comparison of ketanserin and sodium nitroprusside in patients with severe ARDS. Anesthesiology 1988; 68: 152-157.

66. Zapol WM, Rimar S, Gillis N, Marletta M, Bosken CH. Nitric oxide and the lung. Am J Respir Crit Care Med 1994; 149: $1375-1380$.

67. Dinh-Xuan AT, Brunet F, Dhainaut JF. The use, and misuse, of exogenous endothelial-derived vasodilators in acute respiratory failure. Intensive Care Med 1997; 23: 11101118.

68. Singh S, Evans TW. Nitric oxide, the biological mediator of the decade: fact or fiction? Eur Respir J 1997; 10: 699-707.

69. Brett SJ, Hansell DM, Evans TW. Clinical correlates in acute lung injury: response to inhaled nitric oxide. Chest 1998; 114: 1397-1404.

70. Moncada S, Higgs A. The L-arginine-nitric oxide pathway. $N$ Engl J Med 1993; 329: 2000-2012.

71. Frostell C, Fratacci MD, Wain JC, Jones R, Zapol WM. Inhaled nitric oxide. A selective pulmonary vasodilator reversing hypoxic pulmonary vasoconstriction. Circulation 1991; 83: 2038-2047.

72. Fratacci MD, Frostell CG, Chen TY, Wain JC, Robinson DR, Zapol WM. Inhaled nitric oxide. A selective pulmonary vasodilator of heparin-protamine vasoconstriction in sheep. Anesthesiology 1991; 75: 990-999.

73. Weitzberg E, Rudehill A, Alving K, Lundberg JM. Nitric oxide inhalation selectively attenuates pulmonary hypertension and arterial hypoxia in porcine endotoxin shock. Acta Physiol Scand 1991; 143: 51-52.

74. Ogura H, Saitoh D, Johnson AA, Mason AA, Pruitt BA, Cioffi WG. The effect of inhaled nitric oxide on pulmonary ventilation-perfusion matching following smoke inhalation injury. J Trauma 1994; 37: 893-898.

75. Ogura H, Cioffi WG, Offner PJ, Jordan BS, Johnson AA, Pruitt BA. Effect of inhaled nitric oxide on pulmonary function after sepsis in a swine model. Surgery 1994; 116 : 313-321.

76. Sheridan BC, McIntyre RC, Meldrum DR, Fullerton DA. L-arginine prevents lung neutrophil accumulation and preserves pulmonary endothelial function after endotoxin. Am J Physiol 1998; 274: 337-342.

77. Shah NS, Nakayama DK, Jacob TD, et al. Efficacy of inhaled nitric oxide in oleic-acid induced acute lung injury. Crit Care Med 1997; 25: 153-158.

78. Dellinger RP, Zimmerman JL, Taylor RW, et al. Effects of inhaled nitric oxide in patients with acute respiratory distress syndrome: results of a randomized phase 2 trial. Inhaled Nitric Oxide in ARDS Study Group. Crit Care Med 1998; 26: $15-23$.

79. Lundin S, Mang H, Smithies M, Stenqvist O, Frostell C. Inhalation of nitric oxide in acute lung injury: results of a European multicentre study. The European Study Group of Inhaled Nitric Oxide. Intensive Care Med 1999; 25: 911-999.

80. Michael JR, Barton RG, Saffle JR, et al. Inhaled nitric oxide versus conventional therapy: effect on oxygenation in ARDS. Am J Respir Crit Care Med 1998; 157: 1372-1380.

81. Troncy E, Collet JP, Shapiro S, et al. Inhaled nitric oxide in acute respiratory distress syndrome: a pilot randomized controlled study. Am J Respir Crit Care Med 1998; 157: $1483-1488$.

82. Walmrath D, Schneider T, Schermuly R, Olschewski H, Grimminger F, Seeger W. Direct comparison of inhaled nitric oxide and aerosolized prostacyclin in acute respiratory distress syndrome. Am J Respir Crit Care Med 1996; 153: 991-996.

83. Zwissler B, Kemming $\mathrm{G}$, Habbler $\mathrm{O}$, et al. Inhaled prostacyclin (PGI2) versus inhaled nitric oxide in adult respiratory distress syndrome. Am J Respir Crit Care Med 1996; 154: 1671-1677.

84. Puybasset L, Stewart T, Rouby JJ, et al. Inhaled nitric oxide reverses the increase in pulmonary vascular resistance induced by permissive hypercapnia in patients with acute respiratory distress syndrome. Anesthesiology 1994; 80: 1254-1267.

85. Okanu Y, Yoshioka T, Shimouchi A, Satoh T, Kunieda T. Orally active prostacyclin analogue in primary pulmonary hypertension. Lancet 1997; 349: 1365.

86. Papazian L, Roch A, Bregeon F, et al. Inhaled nitric oxide and vasoconstrictors in acute respiratory distress syndrome. Am J Respir Crit Care Med 1999; 160: 473-479.

87. Papazian L, Bregeon F, Gaillat F, et al. Inhaled NO and almitriene bismesylate in patients with acute respiratory distress syndrome: effects of noradrenaline. Eur Respir $J$ 1999; 14: 1283-1289.

88. Gallart L, Lu Q, Puybasset L, Umamaheswara Rao GS, Coriat $\mathrm{P}$, Rouby JJ. Intravenous almitriene combined with inhaled nitric oxide for acute respiratory distress syndrome. The NO Almitriene Study Group. Am J Respir Crit Care Med 1998; 158: 1770-1777.

89. Melot C, Naeije R, Rothschild T, Mertens P, Mols P, Hallemens R. Improvement in ventilation-perfusion matching by almitriene in COPD. Chest 1983; 83: 528-533.

90. Reyes A, Roca J, Rodriguez-Roisin R, Torres A, Ussetti P, Wagner PD. Effect of almitriene on ventilation-perfusion distribution in adult respiratory distress syndrome. Am Rev Respir Dis 1988; 137: 1062-1067.

91. Wysocki M, Delclaux C, Roupie E, et al. Additive effect on gas exchange of inhaled nitric oxide and intravenous almitriene bismesylate in the adult respiratory distress syndrome. Intensive Care Med 1994; 20: 254-259.

92. Rubin LJ, Badesch DB, Barst RJ, et al. Bosentan therapy for pulmonary arterial hypertension. $N$ Engl J Med 2002; 346: 896-903.

93. Ghofrani HA, Wiedemann R, Rose F, et al. Sildenafil for treatment of lung fibrosis and pulmonary hypertension: a randomised controlled trial. Lancet 2002; 360: 895-900. 